\title{
角地建築物の構えからみた建築類型と断片的都市形態の関係 \\ THE RELATIONSHIP BETWEEN BUILDING TYPOLOGY AND URBAN FRAGMENTAL MORPHOLOGY VIEWD FROM BUILDING FRONT OF CORNER BUILDING
}

\author{
藤村龍至*, 佐々木 啓**, 塚本由晴*** \\ Ryuji FUJIMURA, Kei SASAKI and Yoshiharu TSUKAMOTO
}

\begin{abstract}
In this paper, the relationship between building typology and fragmental urban morphology viewed from building front of corner as a common condition covered over Shimo-kitazawa is clarified in order to find out the physical order of the district well known for its complexed and intimate atmosphere. In the first half part, the typology of the corner buildings is led by considering the relationship between building element and volume, and the way how the buildings respond to the corner is clarified. In the latter half part, the conbinations of the corner buildings' type are examined in each corner. As a result, it does not seems that the same type of corner buildings stand next each other, however, linguistic rules such as elements and volumes shared by corner buildings in the district work better to know the relationship between buildings and urbanmorphologies in contemporary fluid urban context.
\end{abstract}

\section{Keywords: Coexistence Area of Residense and Commerce, Corner, Corner Site, Corner Site Unit, \\ Building Front, Fragmental Urban Morphology \\ 住商混在地域, 角, 角地, 角地ユニット, 構え, 断片的都市形態}

\section{1 序 研究の背景 建築類型と断片的都市形態の関係}

わが国においては、建築物はひとつの敷地においてひとつずつ 建築されることが原則とされ、街区や地区、街並、都市など、よ り大きな単位で認識される秩序よりも、建築主の自由が優先され てきた。加えて、高度経済成長後の社会の成熟化に伴う価値観の 多様化、経済的な競争の激化に伴う高度利用化、防災や安全に対 する関心の高まりに伴う重装備化など、建築を取り巻く様々な社 会的な要請によって、規模の大小に関わらず、用途の違いにも拠 らず、無数の独立型建築物が個別の状況に応じて新築や改築を繰 り返す状況がもたらされ、その蓄積は、多様な年代の建築物がラ ンダムに並ぶ独特の都市空間を発達させてきた。

80 年代以降、「都市再生」を揭げた諸政策が世界各地で同時進行 するなかで、わが国においても積極的な規制緩和策の導入により、 島状の大規模再開発が続々と展開され、それぞれの開発区域での 都市デザインが試みられてきたが、ひとたび区域外との関係に注 目すると、その圧倒的な規模の違いや、建築主体の不連続性によっ て、都市風景の断片化がますます加速され、都市形態と呼べるよ
うな集合的な秩序は見いだしにくなっている。しかし、建築の個々 の創作の論理的背景として、都市形態として呼べる何かを措定し ないことには、公共に還元しうる継続的な建築創作のあり方を考 えられないのではないか。

その際、ヨーロッパの諸都市にみられるような街路型の集合住 宅が形成するブロックといった建築類型と都市形態の明快な関係 性をわが国の都市空間において見いだすことは難しいが、一見雑 多に見える独立型建築物の集合による街並がみられる東京におい ても、建築物に働く外的、内的な要因に注目し、複数の建築物の 反復に注目すれば、建築物の集合パタンのなかに都市形態と呼べ る形式性を見いだせる潜在的な可能性を期待できると考えられる。 わが国では 20 世紀を通じて、一方で建築スケールでの建築物 の個別性を維持しながら、他方で都市スケールでの都市形態の連 続性、一体性を評価するような、建築物と都市形態を互いに比較 可能にする共通の建築言語の体系が見いだされてこなかったため、 昨今の大規模な都市再開発が社会的な関心を集める一方、生活者 にとつての「空間」の質についての議論よりも、都市再生という「政

\footnotetext{
* 東京工業大学大学院 博士課程 $\cdot$ 修士 (工学)

** 東京工業大学大学院 修士課程

*** 東京工業大学大学院 准教授. 博士 (工学)

Graduate Student, Graduate School, Tokyo Institute of Technology, M. Eng.

Graduate Student, Graduate School, Tokyo Institute of Technology

Assoc. Prof., Graduate School, Tokyo Institute of Technology, Dr. Eng.
} 
策」が先行する状況に歯止めを掛けることができなかった。そのよ うな背景においては、建築と都市の双方を捉元直す共通の批評軸を 見いだし、新たな価値を創出することが 21 世紀の課題であるとい える。

\section{2 研究の対象と目的}

以上のような問題意識に基づき、本研究では、複数の独立型建築 物の反復によって現れる断片的な都市形態（以下、断片的都市形態） のあり方を捉えていく。そこでは、独立型店舗によって日本の都市 の原則である個別性は共有されているが、それを前提に、商店建築 物は住宅と異なり、購買客を引き寄せるための原則である共同性も また共有されている。

近年小田急電鉄の立体交差化事業（高架化）と大型道路「補助 54 号線」の事業認可によって大規模な再開発が計画されており、 社会的な関心を集めている世田谷区下北沢地区は、東京の代表的な 住商混在地域のひとつである。区画整理等の都市整備がなされてい ないために細かな街路が網目状に広がり、それゆえに住宅スケール の建築物と多くの種類の角が存在する独特の都市空間を形成してお り、開発計画により非常に流動的な状況ではあるが、ここでは同地 区を建筑類型と断片的都市形態の関係を考察する対象として設定す る。

ここでは、下北沢地区の都市空間の特徴を形成していると思われ る角、拉よびそれに面する敷地である角地に注目した。角地という 条件下での同一の要素に注目することによって、建築物のふるまい を問題にしようとするためである。まず、茶沢通り等住宅地との境 界となっている街路によって囲まれた範囲 (図 1) を対象とし、そ のなかから複数の街路が交差または分岐する角を抽出したところ、 130 の事例が得られた。また、角地に面して建つ建築物（以下、角 地建筑物）が同地区においては 446 棟みられ、全建築物 (1136 棟) の $39.2 \%$ を占めていることから、ここでは角地建築物の集合が都 市空間に対して構成上の重要な要素となっていると捉えられる。角 地建築物には一辺で接するもの (118) と二辺で接するもの (328)が みられるが、本研究では角に特徴的な構えをつくる二辺で接道する ものを対象とし、さらに住宅等で塀を持ち、街路から直接建物内に アクセスできないものや、空地を除いた 215 棟の角地建築物を対 象とする。

合流する街路の数から角の種類を検討すると、2つの街路が交差 するL 字角 (6) から順に、三叉路 (79)、四つ角 (19)、五叉路 (1)、 六叉路 (1)、がみられた(表 1$)$ 。これらは複数の街路が一点で合流 するものであるが、合流する点がずれる変形 $(24)$ もみられた。 下北沢地区においては三叉路が最も多く、全体の $60.8 \%(79 / 130)$ を占めている。角地建築物を生む外的な要因としては、東京の高密 度な土地利用による影響が大きいと考元られるものの、内的な要因 として、引きを取って独立して建つ住宅とは異なり、商店が購買客 を引き寄せるため 1 階が「接道する」という与件が内的要因とし て大きく働いており、それらの外的要因と内的要因の相乗が角地 表1 角の種類

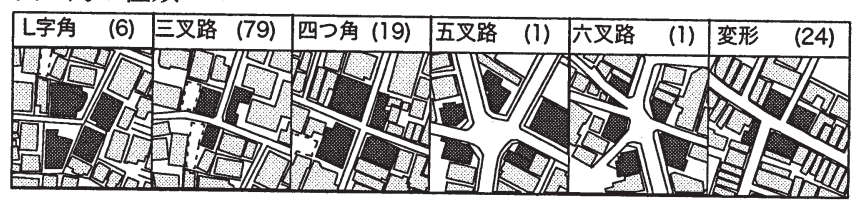

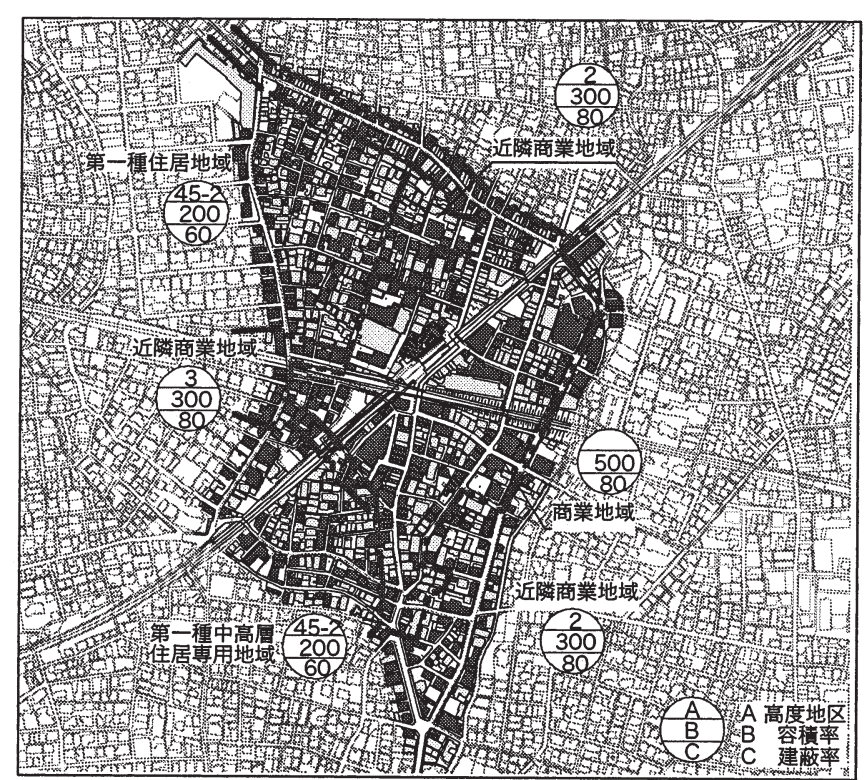

図1 対象範囲

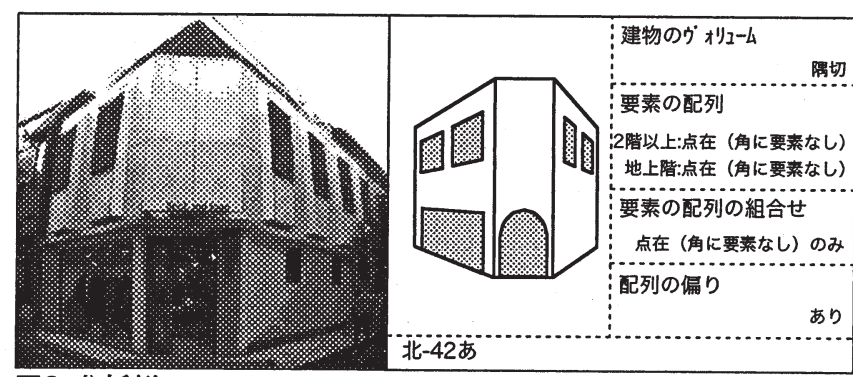

図2 分析例

表2 建築物のヴォリューム

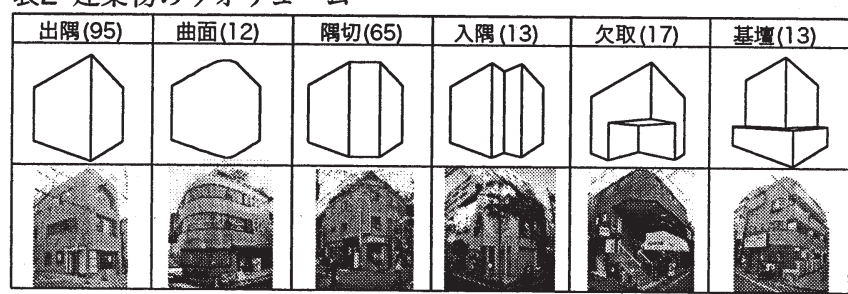

表3 要素の配列

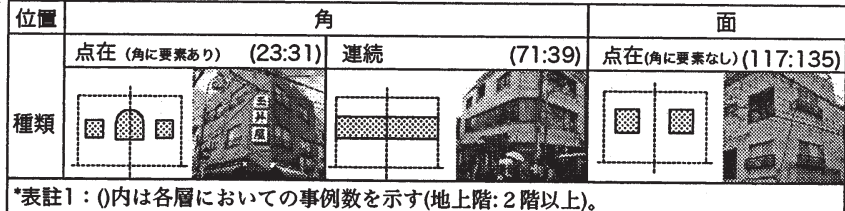

*表註2: 要素がみられないものはなし(1:7)とした。

表4 偏りをもつ要素の配列

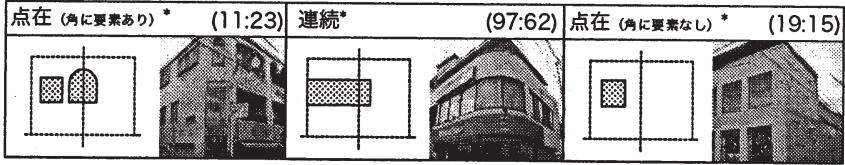

表5 要素の配列の組合せ

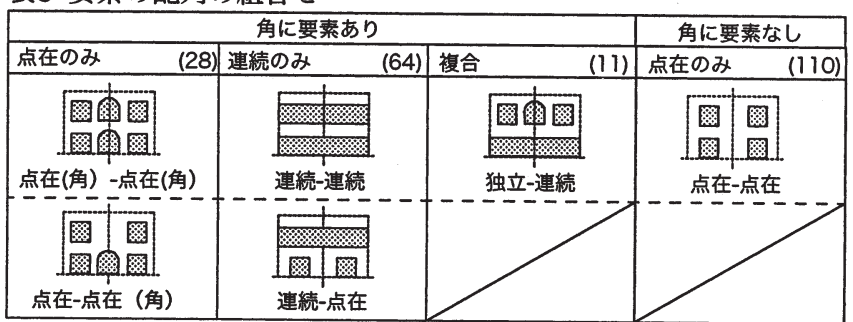


建築物の構えに集中的に現れていると考えられる。ここではまず、 角への対応からみた角地建築物の構えの構成を明らかにする。

さらに、それらの角とそれに面する角地建築物相互の関係に注 目し、同一の角に面する複数の角地建築物の集合を「角地ユニット」 と定義すれば、「ふたつの街路に面する」という共通した物理的条 件に対する複数の建築物の構えを比較することができ、そこには、 小さいながらも単体では成立しない関係的な空間を成立させてい ると捉えることができる。本研究では、下北沢地区に定めた対象 範囲のうち、130の角に面する角地ユニットのうち、住宅のみで 構成されるものを除く 97 の角地ユニットを対象とする。

以上より本研究では、角地建築物という特定の建築類型と、角 という特定の都市の物理的条件との対応関係を観察し、角地建築 物の構えを分析することによって、建築類型と断片的都市形態 の関係の一端を明らかにすることを目的とする。

\section{3 既往研究との関係と研究の概要}

ここで、これまでになされてきた建築類型と断片的都市形態と の関係に関する研究を概観すると、国内外の特定の地域の伝統的 な住宅を対象にし、住居の類型と街区の形態の関係を論じたもの ${ }^{1}$ 、 建築ヴオリュームと周辺環境等街区スケールにおける建築の集合 の形式を論じたもの ${ }^{2)}$ などがみられた。これらの研究では実測等 によって得られた平面図、住宅地図等を資料とし、室やヴォリュー ムの配列などを分析の手段として構成類型を抽出し、その結果を 生活様式や気候風土等の社会的、物理的背景と結びつけた論証な どがなされているが、本研究のように都市的な環境に建つ建築物 を対象とし、角など都市空間に現れる特定の形態を物理的条件と 捉元、両者の関係を論じるという視点はみられない。

本研究ではまず前半部分において、都市形態の構成要素として の角への対応からみた角地建築物の構えの構成要素を明らかにし、 そこで明らかとなった分析格子を用いて、角地建築物の構えの類 型を導く。そして後半部分において、下北沢地区の全ての角にお ける角地建築物の集合の仕方を検討し、そこにおける角地建築物 の類型を比較することによって、建築類型と断片的都市形態の間 に共有されている言語的な規範性のありようを検証するものとす る。

\section{1 角地建築物の構えの構成}

以上のような概要に従い、ここではまず、角への対応からみた 角地建築物の構えの構成を明らかにする。分析例 (図 2)の角地建 築物における角への対応をみると、まず建築物全体のヴオリュー ム形状が隅切りされており、また 1 階店舗の入口は隅切りされて できた面に設けられている。さらに地上階の大きな開口は片側の 道路面にのみ設けられていることがわかる。このように角に対す るヴオリュームの扱い、および開口や看板といった要素の配列に おいては、角ゆえに生じる「二面に接する」という性質 (二面性) と、 道路との接続ゆえに必然的に現れる「地上階／2階以上」という 分節（二層性）が構成上の境界条件となることがわかる。そこで、 これらの性質に注意ながら、建築物全体のヴォリューム形状と要 素の配列についての検討を全資料について行い、同一条件下での 共通した共通した各建築要素のふるまいに注目する。

建築物全体のヴォリューム形状を検討した結果、角への対応と しては、交差点に向かって建物の角を出す出隅 (95)、角をつくら
ず曲面でつなぐ曲面 (12)、隅切りによって角に面をつくる隅切 (65) 角に入隅部分を設ける入隅 (13)、角部の地上階のみセットバック を行う欠取 (17)、2 階以上のヴオリュームがセットバックする基 壇 (13) がみられた (表 2)。下北沢地区においては、角に対して積 極的に関係づける出隅、および隅切が多くを占め、角に対して距離 を取る入隅や、上下階への縦動線を集約する欠取や、二面性よりも 二層性を強調し、上下階をはっきりと分節する基壇はあまりみられ ず、住宅スケールの小規模な商店建築物においても、地上階と道路 との接続が最も重要視されていることがわかる。

次に開口部およびそれと同等の大きさをもつ看板といった要素の 配列を、角への対応を中心に検討した結果、要素の配列が角を中心 にして展開されるものと、面を中心にして展開されるものがみられ た (表 3)。前者については、看板のように角に独立した要素が配列 される点在 (角に要素あり)、水平連空のように要素が角をまたぐ ように連続的に配列される連続、後者については各面に要素が点的 に配列される点在 (角に要素なし) がみられた。地上階および 2 階 以上の事例数をみると、点在 (角に要素あり)および点在 (角に要 素なし)については大きな偏りはみられないのに対し、連続は地上 階に大きく偏っており、地上階における開口の連続性が商店建築物 の構えとして重要であることがわかる。

さらに、各層でのそれらの要素の配列には面毎に偏りがみられ、 それらの組み合わせより、角に点在のみがある点在 (角に要素あり) のみ (28)、連続のみがある連続のみ (64)、独立と連続の両方があ る複合 (11)、角には要素がない点在 (角に要素なし)のみ (110) が みられた (表 4)。下北沢の角地建築物のうち、角に要素があるもの とないものはほぼ半数ずつであり、角を強調する構えを構成する点 在（角に要素あり）のみは全体の $13.1 \%$ にとどまった。

\section{2 角地建築の構えの類型}

以上の検討を踏まえ、出隅、曲面、隅切、入隅、欠取、基壇といっ たヴォリューム形状と、独立、連続、複合、点在といった要素の配 列の組み合わせを各層で検討する。そのなかから、比較的事例が多 くみられ、共通の特徴を持つ 14 の構えの類型を導いた (表 5)。

ヴォリューム形状をもとに順に追っていくと、まず出隅には各

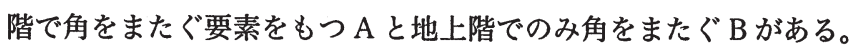
B は人通りのある地上階に対して角を含めた大きな開口をもち、階 によって要素の配列の種類が異なる。出隅の各面に要素が点在する Cは下北沢において最も多くみられた構えであり (72/215)、角に 対してというょりは、側面の二つの街路に対してより強く対応する ものである。

曲面に対して水平連空をもつ D は、角を一枚の面が曲げられた もののように扱うヴオリュームの性格に、水平連空が加わることで より水平方向の連続性を強調する構えである。特に曲面では角をま たぐ要素をもつ構えが多くみられた (10/12)。

隅切には、角が隅切りされることでできる角の面に対して、入口 や看板を設ける E、角の面をまたぐ要素をもつ F、G、看板や開口 を地上階では角をまたぐように、2 階以上では角にもつ H、要素 をもたないIがある。 E は隅切がつくる角の面に対して、各面から 独立した要素を重ねることで、角の垂直性をより強調する構えであ るのに対し、Fでは要素が角をまたぐことで垂直性を弱めている。 Iは角の面に対して要素をもたないことで垂直性を保つものである。 
G、H は B 同様地上階に対して、角を含めてより大きな開口や看板

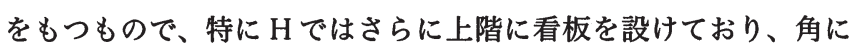
対する複数の応答が重なるものである。このように、隅切は曲面に おける連続のように特定の要素の配列と強い結びつきはみられず、 最も多くの構えのヴァリエーションを生み出すヴオリュームである ことがわかる。

そのほか、入隅には I 同様角の面に対して要素が配列されず各面 に点在するJがみられ、欠取に対しては欠き取られた部分に入口や 開口が集中する K と、各面に開口が点在する Lがあり、基壇には、 街路の形状に合うように突出した地上階のヴォリュームに対して、 角を含めた開口をもつ $\mathrm{M}$ と角に要素をもたない $\mathrm{N}$ がみられた。

このように、角地建筑の構えには角を各面から独立して扱う構 兄 (EIJKL) と、角を水平方向の連続の一部として扱う構え (ABDM)、 これら両方の性格をもつ構え (FGH)、また角には対応せず面する街 路に対してのみ対応する構え $(\mathrm{CN})$ がみられた。さらに角を独立し て扱う構宇には、ヴオリュームがつくる角の単位に要素が配列され ることで独立性を強調するもの (EK) と、ヴオリュームのみにより 独立性を強調するもの $(\mathrm{IJL})$ があり、同様に水平方向の連緬性を強 調する構えには、ヴオリュームと要素の配列が組み合わさることで 連続性が強調されるもの (D) と、要素の配列のみにより強調される もの (ABM) に整理できる。また、両方の性格をもつものは、これ らの互いに相反する性格をもったヴォリュームと要素の配列が組み 合わさることで構えが構成されている。

以上、ここでは住商混在地域である世田谷区下北沢における角地 建築物を対象に、それらの構えをヴオリュームと要素の配列の組み 合わせとして捉觉ることにより 14 の類型を導いた。その特徴とし て、角地建築の構元には角の独立性を強調するものと、水平方向の 連続性を強調するもの、その両方の性格をもつものがみられること を明らかにした。

\section{1 特徵的な角地ユニット}

以上により、角地建築物の構えからそこにみられる建築類型を定 義したが、ここでは前章で定義した角地ユニットを単位とし、それ ぞれの角地建築物の構光の類型を検討することで、角地建築物の類 型とそれらの都市空間への現れとの対応を検討する。

全 97 の角地ユニットに拈ける角地建築物の類型を比較すると、 同じ角地ユニット内に同じヴオリュームや要素の配列が反復すると いった特徴的な事例がみられた。以下それらを順に示す (図 3)。

三叉路である北-12 の角地ユニットの 2 棟の角地建築をみると、 ともに隅切りされたヴォリュームの角に店舗の入口を設け、2 階以 上では開口が角にはなく各面に点在している。また道幅の広い方の 街路に対して大きな開口をとることで、どちらも一方の面に偏りの ある構えをつくっており、ここでは角に対するヴオリューム、要素 の配列それぞれの対応がともに一致した、同じ構えが反復すること で角地ユニットが形成されている。

北 -31の 2 棟では、開口部や看板の位置は異なるものの、とも に地上階で角のヴオリュームが欠き取られており、ヴオリュームに よる角への対応が揃うことで、角にひとまとまりの空間をつくりだ している。

南-14 の角地ユニットではともに地上階で角をまたぐように看板 があり、2 階以上では開口が各面に点在することから要素の配列に
表5 角地建築の構えの類型

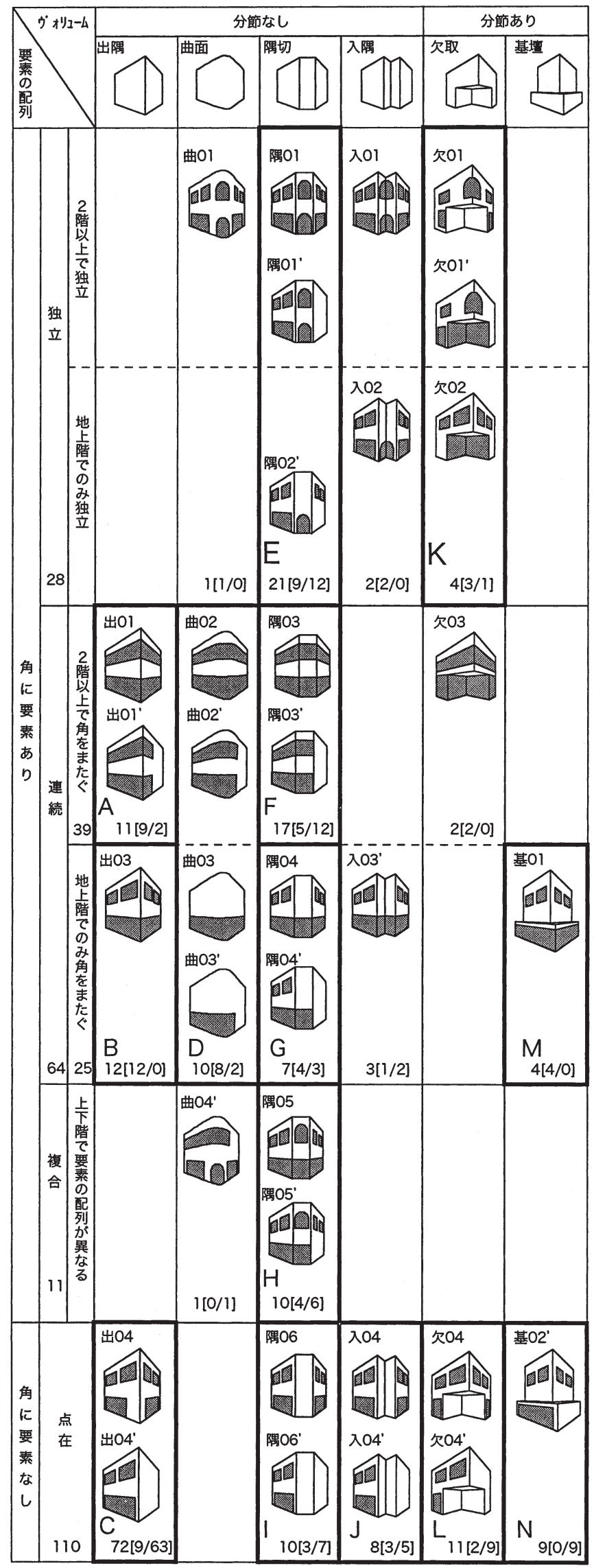

表註1)外クス内の上段に偏りのない構えを、下段に偏りのある構えの事例を図示する。 表註2)表中の数字は事例数を示し、[ ]内はそれぞれ偏りのないもの/あるものを示す。 
よる角への対応が一致しており、2 棟の差はヴオリュームによる角 の扱いのみである。

また 4 棟で構成される角地ユニットをみると、 4 棟全てで同じ構 えが反復する角地ユニットはみられなかったが、北 -33 では、4 棟 の角地建築のヴォリュームが全て隅切りされており、角地ユニット 内でヴオリュームによる角への対応が共通している。

また、北 -9の角地ユニットでは、道幅の広い街路と平行に隣り 合う 2 棟が同じヴオリュームをもちつつ、地上階での要素の配列 は 4 棟で統一されている。曲面のヴォリュームをもつあ、いでは 各面と一体化するように開口部が連続する中で、角に入口を設け、 う、えでは各面に開口をもち、それをつなげるように角をまたいだ 一体的な看板がある。いずれも道幅の差によらず各面を同等に扱 いながらヴオリュームが 2 棟ずつ揃うことで、道幅の広い街路を はさんで対比的な関係をつくっている。ここでは 2 棟ずつでヴオ リュームが揃い、3 棟で要素の配列が揃うといったように複数の水 準で角への対応が一致している。

北-11 の角地ユニットでは、道幅の広い街路に対して、あ、い がともに偏りのある構えをつくるのに対し、う、えでは上下階で角 をまたぐ開口をもち、二辺に対する偏りが少なく、北 -9 同椂街路 を挟んで対比的な関係をつくっているといえる。さらに北-11 は合 流する街路の点がずれており、これに対していは、う、えが面する 角に対して隅切りでできる面に看板を設けることで応答している。

\section{2 角地ユニットと構えの対応関係}

以上、同じ角地ユニットのなかでヴオリュームおよび要素の配 列による角への部分的な応答の一致が見られる角地ユニットが全体 に占める割合を検討したところ (表 7)、そのような一致がみられる 角地ユニットは全体のうち 28.8\%(28/97) で、さらに構えの類型が 一致するものは $5.1 \%(5 / 97)$ にとどまった (表 8)。多くの角地ユニッ トは北-41 に見られるように、角に対して異なる構えをとるものが 隣接するものである (図 4)。このことから、各角地ユニット内では 特定の角地建築物の類型が隣接することはまれであり、下北沢の都 市空間の特徵である角地建築物の集合においては、配列による秩序 を見いだすことができないということが明らかになった。それは角 地建築物としての類型は成立するが、それらを用いて角地ユニット の類型を導くことはできないということである。すなわち、角地建 築物の類型どうしの自由な組み合わせとして角地ユニットを捉えれ ば、それらの集合となる断片的都市形態からなる都市空間の様相は 角地の数だけヴァリエーションを増やしていくようなものとして捉 えられる。

\section{4 結論と考察}

以上本研究では、同一スケールの住宅が並ぶ住宅地のなかに商店 建築物が分散的に混在する状況に注目し、住商混在地域である世田 谷区下北沢の角地建築物 215 棟を対象に、それらの構えを建築物 のヴオリュームと要素の配列の組み合わせとして捉えることにより 14 の類型を導き、その構成的特徵を明らかにした。次に後半部 分において、それぞれの角における角地建築物の集合である角地工 ニットを単位とし、97の角地ユニットに集められた角地建築物の 類型を比較検討することで、角地建築物の都市空間への現れ方や、 それらの相互関係を検討した。
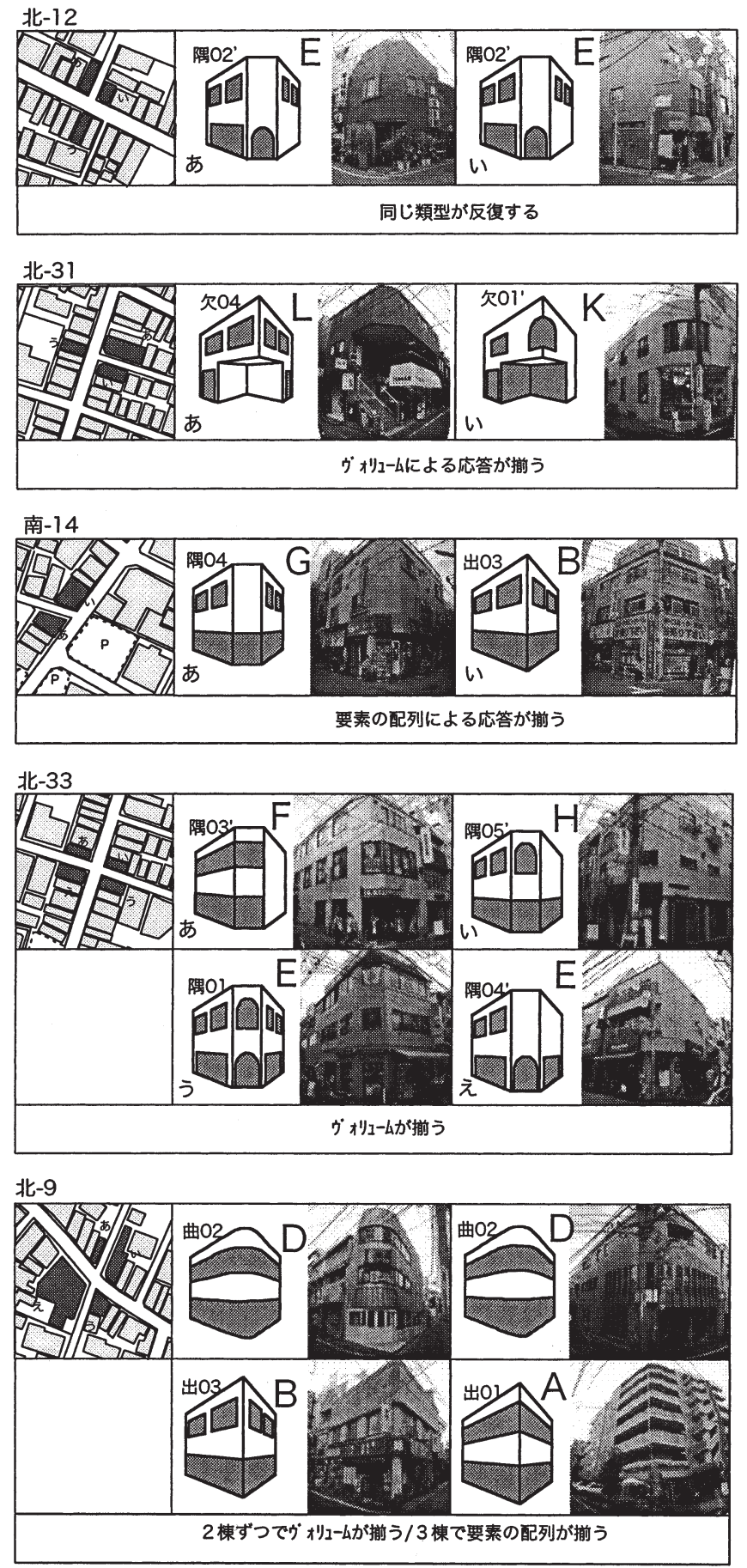

北-11

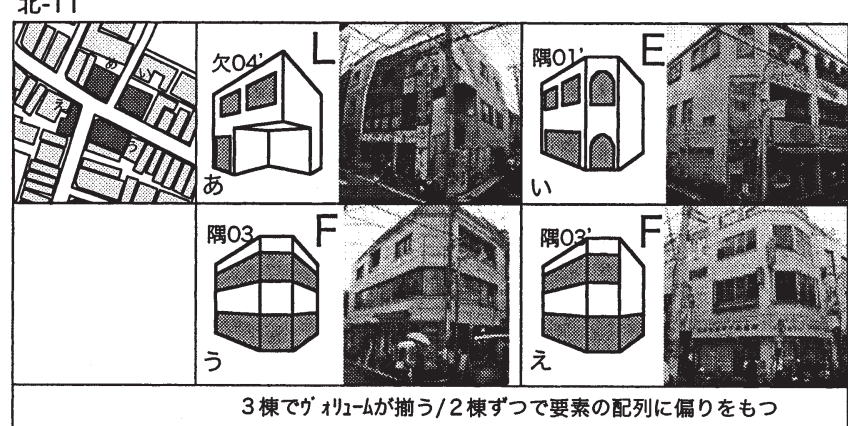

図3 特徵的な角地ユニット 
表7 角地ユニットと構えの対応関係

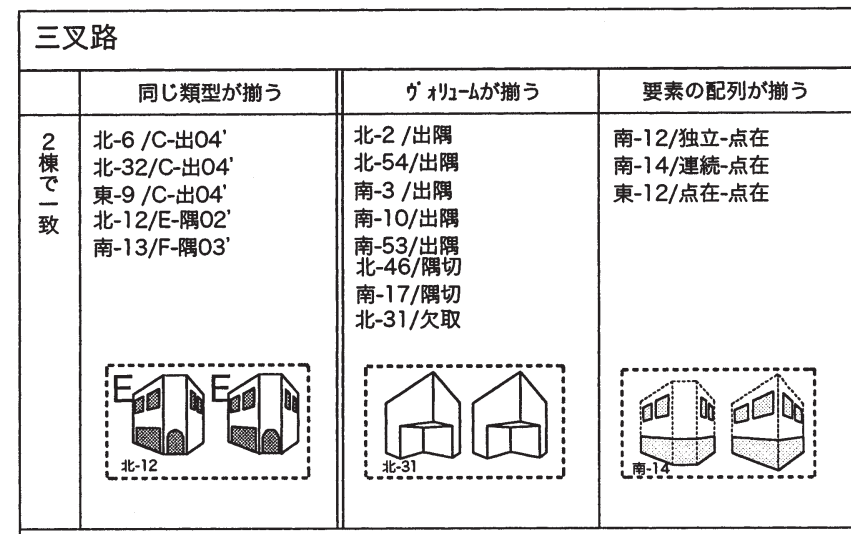

四つ角·変形

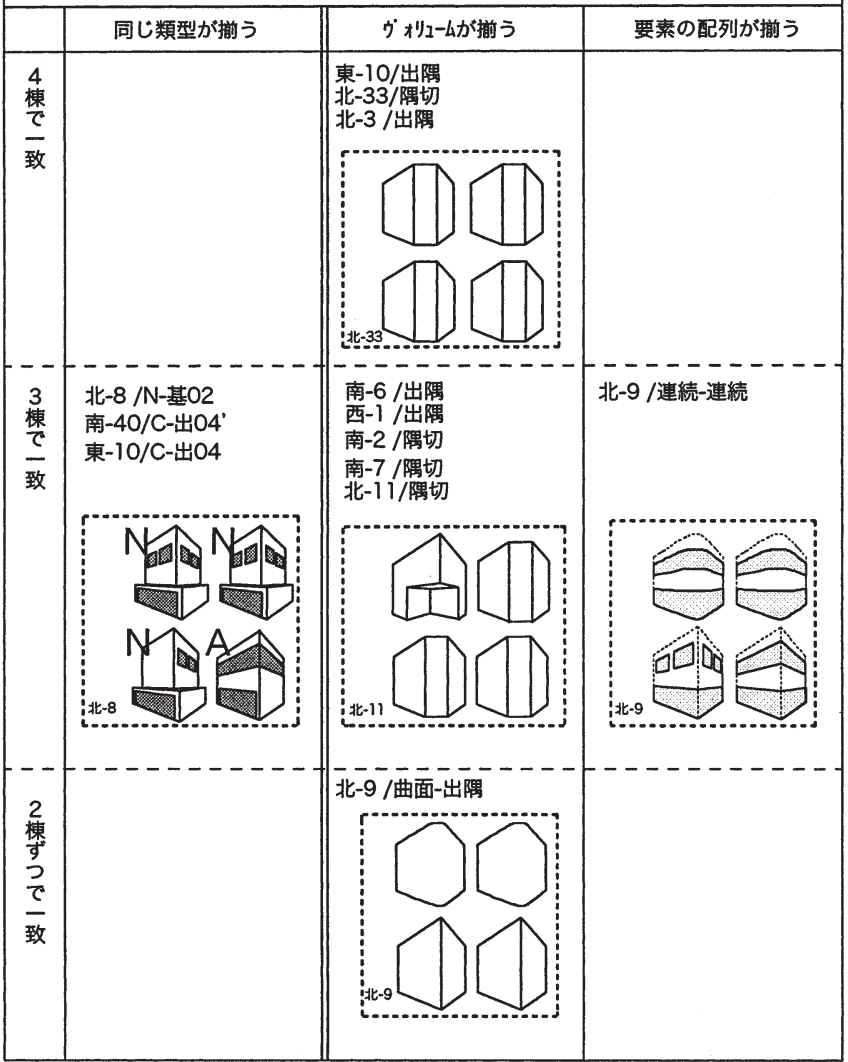

表注) 三叉路、四つ角、組合せ以外の角地ユニットでは構えの一致はみられなかった。

表8 構えの一致がみられる角地ユニット

\begin{tabular}{|l|c|}
\hline 同じ構えが反復する角地ユニット & $5 / 97$ \\
\hline 複数の建物で構えの一致がある角地ユニット & $28 / 97$ \\
\hline
\end{tabular}

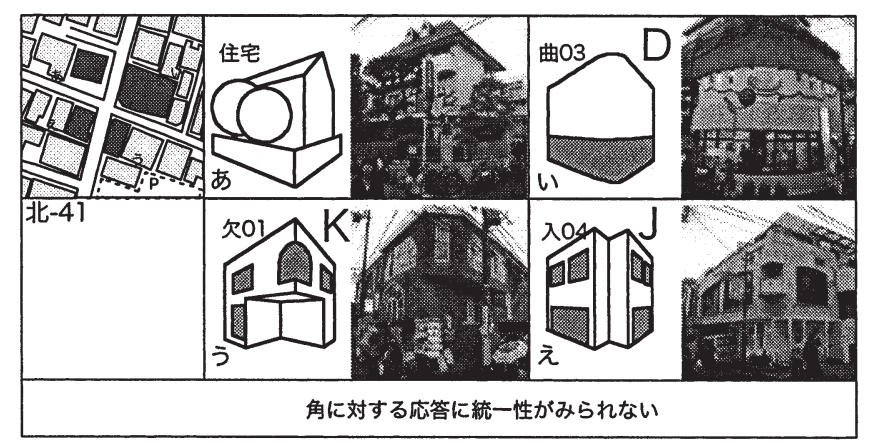

図4 異なる構えがならぶ角地ユニット
その結果、角地ユニットにおいて同じ建築物の類型が隣接するこ とはまれであり、下北沢に視覚的統一性や連続性を見ることはでき ないことが明らかとなった。

しかし、冒頭で述べたように住宅と商店建築物が混在し、区画整 理等の都市整備が行われなかったが故に多くの種類の角が見られる 下北沢においては、全体を一望して得られるような視覚的な秩序、 統一性は感じられないが、一定の時間歩き回ることで得られるよう な体験的な秩序は感じられる。本研究ではそのような秩序を、1 階 や角の扱いなど、部分の取り扱いの方法の共通性に基づく言語的な 規範性として位置づけた。その前提として、接地階の開口と非接地 階の大きな差のある商慣習の一部として角地建築物に共有されてい る二面性、二層性を、要素の配列やヴォリュームの分節などによる 建築物のふるまいを一定の範囲に収める働きをするものとして位置 づけた。

このように、建築類型と断片的都市形態の関係を検討することに よって、視覚的秩序が簡単に捉えられず流動的と言われる東京のよ うな都市環境においては、均質性や様式的統一性によって建築物の 集合を捉えることはあまり有効とは言えず、むしろ特定の場所や特 定の種類の建築物に固有の建築の形式言語を仮想する方が、建築と 都市の双方を読解・構築する上で有効であるとの認識を得ることが できた。この認識に基づいて、今後さらに場所の固有性を建築の言 語の水準において再構築する可能性についても検討を加えていくこ ととしたい。

注 注 1) 本研究は, 藤村龍至, 佐々木啓, 塚本由晴ほか:「角地建築の構元 構 えからみた下北沢における角地建築の類型 (1)」「角地ユニットからみた都市 空間の性格 構えからみた下北沢における角地建築の類型 (2)」, 2007 年度 日本建筑学会学術講演会における発表論文 (梗概集 F-2, pp.717-720) とし て一部報告したものを、改めてまとめたものである。

注 2 ) ここでいう「断片的都市形態」の定義とは、直交グリッドではない交 差点の反復のなかに位置づけられる「角の種類と集合の仕方」のことである。

\section{参考文献}

1) 山田協太, 前田昌弘, 村上和, 布野修司：「ヴオルフェンダール（コロ ンボ, スリランカ）の街区構成と住居類型」日本建築学会計画系論文集 No.607, pp.71-78, 2006.9

2）美濃部幸郎, 坂本一成, 寺内美紀子:「周辺環境との隣接関係からみた都 市建築の統合形式 : ヴオリュームの配列による現代建築の統合形式に関す る研究」日本建築学会計画系論文集 No.558, pp.137-144, 2002.8 